\title{
Conceptual Framework: The Role of Microfinance on the Wellbeing of Poor People Cases Studies from Malaysia and Yemen
}

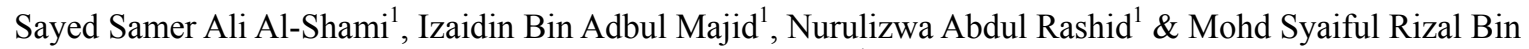 \\ Abdul Hamid ${ }^{1}$ \\ ${ }^{1}$ Faculty of Technology Management \& Technopreneurship, Universit Teknikal Malaysia Melaka, Malaysia \\ Correspondence: Sayed Samer Ali Al-Shami, Faculty of Technology Management \& Technopreneurship, \\ Universit Teknikal Malaysia Melaka, Malaysia. E-mail: sam.alshami@yahoo.com
}

Received: October 9, 2013 Accepted: November 6, 2013 Online Published: December 31, 2013

doi:10.5539/ass.v10n1p230 URL: http://dx.doi.org/10.5539/ass.v10n1p230

\begin{abstract}
The role of microfinance institutions in poverty reduction and wellbeing improvement has attracted the policymakers' attention in the developing countries across the globe as well as Malaysia and Yemen. The underlying logic is that by providing microfinance services, poor will be able to participate in the economic market through forming their small businesses. Consequently, they will be able to generate income and improve their households, self esteem and efficacy. Despite the popularity and apparent success of microfinance, there is no clear evidence that asserts the positive impact of microfinance scheme. Therefore, the aim of this research is to propose a conceptual framework in the role of Malaysian and Yemeni microfinance on the poor' wellbeing. Microfinance servers refer to financial, nonfinancial and social services while the clients' wellbeing refers to the clients' household, micro and small enterprises performance and empowerment. The mixed method is employed to carry out the objective of this research. The cross-sectional survey with the randomized control trait is used for collecting the quantitative data while the regression logistic with chi-squire are used to analysis. In contrast, the semi interview is conducted to collect and analysis qualitative data. The three microfinance institutions of Amanah Ikhtir Malaysia, Yayasan Usaha Maju and Economic Fund for National Entrepreneurs represented Malaysian microfinance while the Al-Amel Bank represented Yemeni microfinance.
\end{abstract}

Keyword: microfinance, wellbeing, Malaysia, Yemen

\section{Introduction}

Alleviating poverty and creating jobs are at the heart of the socioeconomic development goals. They have become main targets of unprecedented attention at many developing and undeveloped countries. Microfinance has shown to be an effective tool for combating poverty, creating jobs, and improving the wellbeing of poor. It has also proven to be an engine to poor empowerment especially women through enabling them to manage their businesses and make their decision independently and enhance their self-esteem as well as their self efficacy. Furthermore, it considered as a crucial vehicle to driving the achievement of the millennium development goals of halving hunger and extreme poverty by 2015 , promoting gender equality and achieving universal primary education.

Generally microfinance is known as a provision of a wide range of financial services such as credit, insurance, savings, deposit and payment services to poor and low-income households who are excluded from conventional financial services for lack collateral (Johnson \& Rogaly, 1997; Ledgerwood, 1999; Littlefield, Murduch, \& Hashemi, 2003; Robinson, 2001). The underlying logic is that by offering financial services, poor and low income people will be able to participate in economic market through forming and developing their micro and small enterprises. Consequently, they will be able to improve their households, manage their businesses and make their decisions independently. The policymakers in Malaysia and Yemen recognized the importance of microfinance to achieve socioeconomic and millennium development goals. Therefore, they established many institutions to deliver financial and nonfinancial services that are needed by a large size of people who live in poverty and deprived from accessing to formal financial services.

\subsection{Basic Concept}

The concept of microfinance is defined differently according to the objective of the scheme, the type of offered 
products and from the perspective of microfinance users. CGAP (2013) used to say that "Microfinance is often defined as financial services for poor and low-income clients. In practice, the term is often used more narrowly to refer to loans and other services from providers that identify themselves as - microfinance institutions (MFIs) These institutions commonly tend to use new methods developed over the last 30 years to deliver very small loans to unsalaried borrowers, taking little or no collateral. These methods include group lending and liability, pre-loan savings requirements, gradually increasing loan sizes, and an implicit guarantee of ready access to future loans if present loans are repaid fully and promptly". One more to the definition above, Robinson (2001) extends the scope of the definition to include the rationale for the provision of microfinance products. He, says that "microfinance refers to small scale financial services primarily credit and savings-provided to people who farm or fish or herd; who operate small enterprises or small business enterprises where goods are produced, recycled, repaired, or sold; who provide services; who work for wages and commissions; who gain income from renting out small amounts of land, vehicles, draft animals, or machinery and tools; and to other individuals and groups at the local levels of developing countries, both rural and urban". Furthermore, Schreiner (2000) describes microfinance as formal schemes designed to improve the well-being of the poor through better access to saving services and loans. He suggests that the services that provide by informal financial sector such as money lenders, pawn shops, check cashing outlets, and loans among relatives and friends all are important source to poor and important knowledge to microfinance institutions to discover the poor of people.

The above definitions have shown a general understanding on microfinance that offer by microfinance institutions. Yet, those definitions have narrowed the scope of microfinance on the financial services only while non financial and social services have been excluded. In contrast, Ledgerwood (1999a) provides a quite definition of microfinance and he states that, "the term of microfinance refers to the provision of financial services to low-income clients, including the self-employed. Financial services generally include savings and credit; however some microfinance organisations provide insurance and payment services. In addition to financial intermediation, many MFIs provide social intermediation services such as group formation, development of self-confidence and training in financial literacy and management capabilities among members of a group. Thus the definition of microfinance often includes both financial intermediation and social intermediation. Microfinance is not simply banking, it is a developmental tool. Microfinance activities usually involve:

1) Small loans typically for working capital

2) Informal appraisal of borrowers and investments

3) Collateral substitutes, such as group guarantees and compulsory savings

4) Access to repeat and larger loans, based on repayment performance

5) Streamlined loan disbursement and monitoring

6) Secure saving products.

\subsection{Problem Statement}

A surge of growth in the microfinance institutions has been noticed in the developing countries especially in Asian countries in the last two decades. Microcredit Summit Campaign (2012) reports that the number of the poorest clients with microcredit has grown from 7.6 million in 1997 to 137.5 million in 2010 . It also found that at among of those poorest clients over than 113 million were women. This number was resulted of 3,652 microfinance institutions around the world. The Malaysian and Yemeni MFIs have also witnessed a remarkable growth in the number of institutions and clients. The birth of Malaysian MFI was in 1987 when Malaysian government decided to replicate Grameen bank model of group-lending and establish Amanah Ikhtiar Malaysia (AIM) as non government organization. The main aim of (AIM) was to provide financial services to those who were excluded from accessing to formal financial services for lack collateral. Recently, (AIM) is the largest MFI in Malaysia which services approximately 82 percent with 222,557 of Malaysian poor households (Omar, Noor, $\&$ Dahalan, 2012). It also was reported to have the highest loan repayment rate in the world which reached 99.2 percent (Monitor, 2010). The (AIM) loan is free interest based on Islamic principles, except $10 \%$ as operational and management fees with $2 \%$ as a compulsory saving. The second microfinance institution is Yayasan Usaha Maju (YUM). It was founded in 1988 as a government institution under the ministry of agriculture. The mission of this institution is to provide financial services to poor and low income people who live in Sabah state. The (YUM) provides loan with free interest except $10-18 \%$ as a managerial and operational fees with $2 \%$ compulsory saving. Currently, (YUM) services 8,252 borrowers through 20 branches and it has a good repayment rate which scored 90.72. The third microfinance institution is Economic Fund for National Entrepreneurs Group (TEKUN) 
which was founded in 1998 as a government institution under the ministry of agriculture. The mission of this institution is to provide financial services to all entrepreneurs with regardless to their economic statue either poor or not. The (TEKUN) offers loan with free interest except $4 \%$ as managerial fees and $5 \%$ compulsory saving. Currently, (TEKUN) is providing its services from 194 branches to 150,131 clients. The loan repayment rate in the (TEKUN) is $85.0 \%$ which considers low compared to the repayment rates in the (AIM) and (YUM).

In contrast, the effective role of Grameen Bank in poverty reduction and job creation in Bangladesh has attracted the policymakers' attention in Yemen and motivated them to replicate the Grameen Bank Model. Indeed, Yemen has replicated Grameen Bank Model and established the social fund for development in 1997 as a first microfinance institution. Yemen microfinance was tailored to contribute to the achievement of millennium development goals (MDGs) of halving hunger and extreme poverty, creating jobs as well as improve gender equality (Mansour, 2011). Due to the steadily growth of microfinance demand, Yemen government established Al-Amel bank in 2009 as a joint collaboration between the Yemeni government's Social Fund for Development, Arab Gulf Programme for Development (AGFUND), and private sector shareholders. Nowadays, the Yemen microfinance has rapidly grown to reach ten institutions and 67, 449 active.

Recently, a few number of impact assessment studies have been conducted to uncover the role of the Malaysian and Yemeni microfinance institutions on the clients' wellbeing, empowerment and their micro and small enterprises. For instance, studies by Nawai and Shariff (2011), Mokhtar (2011), Hamdan, Othman, and Hussin (2012), Mamun, Adaikalam, and Wahab (2012), and Omar et al. (2012) confirm that the Malaysian MFIs have significant positive impact on the clients' wellbeing and their micro and small enterprises performance. This impact has manifested in increasing the clients' asset acquisition and income generation at the household level and micro and small enterprises level as well as empowerment level. In contrast, very few studies have been conducted to explore the impact of the Yemeni microfinance institutions on their clients' wellbeing and their micro and small businesses performance. Ahmad (2012) and Burjorjee and Jennings (2008) asserted that the Yemeni microfinance institution is a crucial mechanism for combating the poverty and improving the wellbeing of many poor as well as their micro and small businesses. They indicated that microfinance service helps poor to increase their households' income, improve educational enrolment of their children and enhance the quality of their life. In contrast, microfinance has a positive impact on the performance of micro and small businesses. It helps poor to enhance the income and size of their micro and small enterprises.

Despite, the majority of Malaysian and Yemeni microfinance studies confirm the significant role of the microfinance on the clients' wellbeing; they were not immune of criticisms. First, the majority of those studies have paid considerable attention to the output of microfinance rather than inputs and outputs. Second, a few numbers of those studies shed a little light on the financial intermediation services generally and loan particularly. Nonetheless, the determinants of nonfinancial services, social intermediation services have not received a considerable attention. Third, the measurement of microfinance performance was predominately based on the economical performance such as household and micro and small businesses' income and expenditure. Notwithstanding, measuring uneconomical performance such as empowerment, household improvements, health and nutrition were almost excluded. Finally, the integration of qualitative and quantitative methodologies is important to carry out the impact assessment of microfinance services where the majority of target respondents are not educated and from rural areas (Ledgerwood, 1999). Ironically however, the majority of the Malaysian and Yemeni microfinance studies had been conducted based on quantitative or qualitative methods separately.

All those limitations left gaps and spawned a question "what is the role of microfinance on the clients' wellbeing? In order to fill those gaps and answer the research question, the present research is aimed to investigate the role of microfinance services on the wellbeing of the users' services of microfinance in Malaysia and Yemen. Microfinance services in this research refer to financial, non financial and social services. Financial service refers to loan disbursement and repayment services and saving services while nonfinancial services include enterprises development trainings. In addition, social service is referred to the group formation and social capital services. The indicators of wellbeing involve the economical, human development and empowerment indicators. The economical indicators refer to the microenterprise profit, income, revenue, assets, and household expenditure such as food-non food, assets and others, while the human development indicators contain the business skills, education (enrolment and achievements for adults and children), health and health behaviour as well as nutrition. In addition, the empowerment indicators involve the ability to cope with uncertain shocks, ability to make the decision and manage business independently and the self esteem as well as self efficacy. The mixed method of quantitative and qualitative approaches is used to carry out the objectives and answer research question. 


\section{Literature Review}

Micro-financing is not a new concept it can be traced back to the late of three centuries before when the Friedrich Willelem Raiffeisen established the first cooperative lending banks to support farmers in rural Germany. However, the modern concept of microfinance was found in 1970s when Muhammad Yunus established Grameen bank in Bangladesh. The successful experience of Grameen Bank in combating the poverty and flourishing the economic wellbeing of poor has attracted many government and nongovernment organizations attention to the possibility of replicating this experience. Indeed, a surge growth of microfinance institutions has been noticed in the developing countries especially in Asian countries since the birth of the Grameen Bank in 1975. Microcredit Summit Campaign (2012) reports that the number of the poorest clients with microcredit has grown from 7.6 million in 1997 to 137.5 million in 2010 . It also found that at among of those poorest clients over than 113 million were women. This number has been collected from 31,652 microfinance institutions around the world.

Microfinance has gained a universal consensus as an effective tool for alleviating poverty and wellbeing improvement (Bakhtiari, 2006; Ebimobowei, Sophia, \& Wisdom, 2012; Imai \& Azam, 2010; Johnson \& Rogaly, 1997; Ledgerwood, 1999). It also seen as an approach to help the local economy (Johnson \& Rogaly, 1997). The dynamic growth of microfinance activities can lead to the achievement of a wide range of development objectives, including: the fulfilment of self-employment, new firms formation, and income distribution (Bakhtiari, 2006; Johnson \& Rogaly, 1997; Khandker, 2005; Ledgerwood, 1999; Littlefield et al., 2003). The role of microfinance goes beyond business investment, to include the improvement of the economic wellbeing of households. For instance, clients' health, nutrition, children education and standard of their life (Angioloni, Kudabaev, Ames, \& Werzstein, 2013; Dunford, 2001; Holvoet, 2004; Littlefield et al., 2003; Morduch., 1999). Microfinance also considers as an essential approach to empower poor especially women (Littlefield et al., 2003; Swaina \& Wallentin, 2009). It enables them to make their decision independently, improve the quality of their life and dignity (Johnson \& Rogaly, 1997; Ledgerwood, 1999; Narayan, 2002).

Over the past three decades, impact assessment studies and researches in the field of microfinance have witnessed a dramatically growth among academic schools. However the majority of those studies paid great attention to the measurements of microfinance outputs rather than outputs and inputs (Hulme, 2000). Recently, many microfinance studies started to recognize the importance of assessing the input and output of microfinance for approve the impact of microfinance and improve microfinance implementation. The output of microfinance is differed from one institution to another according to the model of microfinance and the type of the provided product. For instance, microfinance can be a group scheme where the group members form themselves in a joint liability group and take loans under the social collateral while the group members are responsible to repay any default loan. In contrast, microfinance can be individual scheme which services individual borrowers. Furthermore, some microfinance institutions provide financial services such as loan, saving, insurance services while others provide financial and nonfinancial products such as enterprises development training, skills acquisition trainings, social capital services and others. Therefore, the output of microfinance performance is usually subject to several criteria which may vary from one study to another (Ledgerwood, 1999; Robinson, 2001).

\subsection{Financial Services}

\subsubsection{Microcredit}

Financial services such as microcredit saving and repayment services are the main tools of microfinance institutions which have the power to help developing countries in their battle against poverty and advance families' wellbeing. The formal birth of microcredit was in 1970 when the professor Mohamed Yunus who is the Bangladeshi banker introduced credit services in the Carmen Bank. Nowadays, microcredit becomes a buzzword among the formal and informal moneylenders which includes pawn shops, friends and relatives, informal groups, non government organization credit, and the provided credit of conventional banks such as agricultural, livestock credit and others. The main reason behind the popularity of microcredit in the moneylenders' market is owed to its goal of serving poor people and alleviating their poverty, while other types of moneylender are motivated by profit. Moreover, the given loan is required social collateral rather than physical collateral which opens a wide window for poor to participate in the economic market and exploit the exits opportunities. The concept of microcredit is referred to the small amount of credit given to poor people especially women at reasonable interest for generates income through self-employment. The importance of microcredit can be interpreted from different angles. It can be seen from empowerment angle as a human right because it empowers the most vulnerable people especially women through enabling them to get job and generate income. Haile, Bock, and Folmer (2012) 
indicated that microcredit empowers women in Ethiopia through allowing them to improve their ability in decision making and gain money as well as enhance their household expenditures. Microcredit is also read from the angle of the sustainable livelihood approach because it reduces the poverty and enhances the wellbeing of poor. Garikipati (2008) emphasised that microcredit allows poor to advance the quality of their life through enabling poor to generate income and acquire assets in India. Nader (2008) confirmed that microcredit played a significant role in the families' wellbeing in Cairo. It helps them to gain assets and generate income, improve children's education as well as advance their health condition and harmony. Mokhtar (2011) underlined to the significant role of microcredit in enhancing clients' income, assets and the quality of their life in Malaysia. Microcredit can also interpret as a tool of economic development because it promotes start-up new business, reducing poverty and creating jobs. Mamun et al. (2012) assured to the important of microcredit on businesses' development and job creation in the Malaysian microfinance's clients. In contrast, Ahmad (2012) and Burjorjee and Jennings (2008) demonstrated that microcredit has a positive impact on the women entrepreneurs in Yemen through stimulating new businesses formation and reducing poverty.

Recently, scholars and researchers from various disciplines started to recognize the importance of the loan terms to the clients' performance which includes repayment flexibility, loan size, interest rate and others. Repayment policy may mean the utmost importance to the beneficiaries especially poor who face high level of risks and they lack the capability of managing their loan. Rutherford, Maniruzzaman, Sinha, and Acnabin (2003) indicated that the flexibility and rescheduled loan repayment had been considered by the Grameen II model to secure borrowers of loan default and facilitate the process of getting loan. Yeboah (2010) emphasised to significance role of loan flexibility on the clients' households' and their businesses performance in Ghana. Field, Pande, and Park (2012) said that loan flexibility is a key player to stimulate microfinance clients to invest their loans more profitably and reduce financial stress in India. Moreover, the impact of microcredit in the clients' household and their micro and small enterprises lies on the size and number of the given loans at a given period. Hamdan et al. (2012) and Mokhtar (2011) also indicated that the purpose of loan usage, size and numbers are the main factors that influence borrowers' income in the Malaysian microfinance institutions. Moreover, Mamun et al. (2012) suggested that the Amanah Ikhtiar Malaysia's should offer diversified products and services through expending group loan size, provide fixed asset loan, working capital loan, car loan, seasonal agricultural loan, , emergency loan, consumer loan and parallel loan. In the same vein, Simeyo, L, R, O, and Odondo (2011) assumed that extending the size of the given loan will lead to improve the performance of the Kenyan youth entrepreneurs. Furthermore, Godquin (2004) indicated that the Bangladeshi MFIs tend to increase automatically the size of the loan with increasing the loan cycle and age of the group borrowing.

\subsubsection{Transaction Cost}

Microfinance institutions were heavily reliant on the government and nongovernment subsidies to cover the operational cost and provide the poor borrowers financial services with cheap credit. However, in order to achieve deep outreach, the sustainability and independency of financial system are required. Many scholars from different schools made considerable efforts to develop financial system that enables microfinance to achieve the sustainability in the market and simultaneously achieve deep outreach. Robinson (2001) stresses that microfinance can attain a wide outreach sustainably through establishing self-sufficient commercial institutions that are outside the subsidized credit model. Christen and Drake (2002. p. 4) used to define the concept of microfinance commercialization as "movement out of the heavily donor-dependent arena of subsidized operations into one in which microfinance institutions 'manage on a business basis' as part of the regulated financial system". The commercialization of microfinance is seen as an essential approach to consolidate the sustainability and outreach of microfinance institutions through providing permanent sources of funding and establishing financial viability and scale. Christen and Drake (2002. p. 5) identified two types of institutional commercialization: (1) microfinance (NGO) that have transformed into bank or licensed nonbank financial intermediaries and (2) is large retail banks (including state-owned institutions). While Ledgerwood and White (2006) defines three ways to commercialize microfinance institutions which are: (1) shifting a non-profit entity into a financial institution, (2) establish a commercial MFI from scratch and (3) involving microfinance services in the traditional banks services. Charitonenko and Afwan (2003) links between the objectives of institutional commercialization of microfinance and the sources of fund as shown in figure (1). The objectives of commercializing microfinance institutions are to extend the outreach services, achieve operational self-sufficiency and financial sufficiency. In contrast, to meet these objectives it is important to synthesize the sources of microfinance fund which can be obtained through applying and increasing cost recovery interest rates, using non-subsidised loan, mobilization of voluntary savings, or other market-based funding sources. 


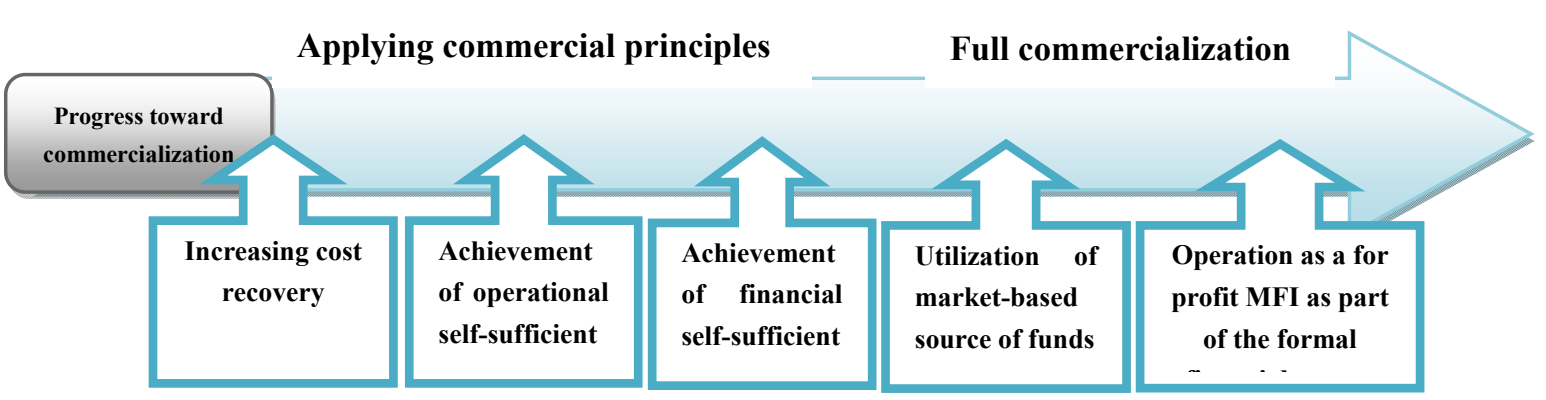

Charitonenko and Afwan (2003)

Figure 1. Attributes of MFI commercialization

Despite, the insistent to commercialize microfinance institution that was supported by the advocates of institutional school, the advocates of social school argue that the commercialization of microfinance maybe drift the mission of microfinance. Morduch and Hayley (2002) argue that the goal of financial sustainability is to achieve high repayment rates and low overheads and it can be achieved through providing services in areas which are cheap and easy to reach and to people who have the capability to repay the loan. Nonetheless, the poor people who live isolated and more vulnerable maybe deprived of accessing to the financial services because they are seen as risks. Regardless the supporters and opponents of commercializing microfinance, measuring the impact of microcredit cost is an important determinant to address the performance of microfinance institutions and their clients. Kodongo and Kendi (2013) argued that a high interest rate on the loan is a main cause of loan default in the Kenyan microfinance institutions. In the same vein, Behr and Sonnekalb (2012) recommended that increasing repayment incentives are important for positive effect on loan performance in commercial bank in Albania.

\subsubsection{Saving}

Transforming microfinance institutions from depending on the government grant and donor funds into self-sufficient has accompanied with the needs to diversify their products and consolidate their market share. In order to achieve that, microfinance institutions have been tailored saving products to relieve unexpected shocks that maybe face poor and enhance their repayment rate as well as support the financial position of microfinance institutions. There are different types of savings services that are offered by MFIs such as insurance, deposits, compulsory and voluntary and others. However, the most common ones are voluntary and mandatory savings. Mandatory saving is referred to the value of savings that the clients of microfinance are required to save as a condition of obtaining future loan. Mandatory savings can be either a facilitated savings account kept outside of the MFI or a deposit held by an MFI. In contrast, voluntary savings is referred to the amount of savings kept by MFI clients which is not required as a condition of an existing to loan. Voluntary savings can be facilitated savings which kept outside the MFI as part of the MFI's overall financial services or deposits held by an MFI. Wisniwski (1998) indicated that the advantages of saving service can be read from the perspective of the clients as well as microfinance institutions. On one hand, saving services are a valuable mechanism to clients for liquidity management through accessibility to cash, rate of return, security and divisibility of savings. On the other hand, savings are vital and attractive source to microfinance for three reasons: - (a) important source for microfinance funds which can be easily obtained with lower cost, (b) withdrawals small amounts of money from saving account do not lead to liquidity risk compare to large savings, (c) small deposits and savings are more steady capital source than re-deducted it from the Central Banks or donor funds. (d) deposit-taking can create strong market-demand for microfinance institutions and improve their operations. Savings products are also important to poor which help them to reduce the financial cost of lending and secure a sustainable fund sources (Ledgerwood, 1999; Robinson, 2001). In same vein Brannen (2010) confirmed that savings services that provided by the Village Savings and Loan Association Program in Zanzibar, Tanzania has the capacity to ameliorate the clients' livelihood and their families as well as empower them.

\subsection{Nonfinancial Services}

The financial services that provided by MFIs are important sources for job creation, new businesses formation, and livelihoods improvement. However, financial services alone are not enough to continuously improving the livelihood of the clients and enhancing the sustainability of their micro and small businesses. Thus, the necessity 
of integrated nonfinancial services and microcredit has been recommended by many studies and researchers. Ledgerwood (1999) declares that microfinance is not a simple bank; it is a development tool of human skills to effectively use financial sources. Morduch and Hayley (2002) point out that the entrepreneurial skills and ability are essential to drive a successful microenterprise and not all microfinance institutions' clients are evenly able to take on credit.

Recently, a few studies in the field of microfinance have approved the importance of nonfinancial services on the clients' households and their micro and small enterprises' performance. Karlan and Valdivia. (2006) assured to the importance of entrepreneurial training that provided by Peruvian village banking programme on the clients' savings, loan repayment and retentions rates and businesses' knowledge. Hamdan et al. (2012) recommended that the clients of the Malaysian microfinance institutions should be engaged in entrepreneurial and business skills trainings before start operationalizing their microenterprises. Mensah and Benedict (2010) argue that the entrepreneurship training has a potential to enhance the capacity of micro and small enterprises for jobs creation and growth in the South of Africa. They also assert that the entrepreneurial trainings will be more effective when combined with microcredit service. Parvin, Rahman, and Jia (2012) postulate that easily access to credit, skill training availability, access to information membership with development organizations are important to successfully driving women to micro entrepreneurship in Bangladesh.

Micro and small business is an important source for developing Malaysian economy; it accounts $78.7 \%$ of business establishment and $80 \%$ of small and medium enterprises (SMEs) (Statistics, 2005). Nonetheless, there are several constraints to MEs development, such as lack of relevant laws and administrative procedures; a lack of or limited access to institutional credit; imperfect market information and lack of opportunities for skill development (Nawai \& Shariff, 2011). Entrepreneurship training has recognized to inspire women entrepreneurs and advance their micro and small enterprises. The integration between financial and nonfinancial services has been recommended as a proxy to boost micro and small enterprises and advance the clients livelihoods. But, this integration might be costly compared to the promised benefits. Therefore, non government and government subsidies are needed to cover the cost of nonfinancial services that provided by microfinance institutions to poor. Mutua (1994, p. 268) states that it became obvious that the 'integrated' method of developing microenterprises, which combined traditional methods of making loans with intensive entrepreneur training and technical assistance, had limited impact on the beneficiaries, was costly, and could be sustained or expanded only through grant funding.

\subsection{Social Intermediation Services}

It is an open secret that microfinance is an urgent need to help the poor to create jobs and improve the standard of their life. However, microfinance institutions always face twofold problem when financing poor borrowers. This problem is caused by the inability of poor to provide physical collateral, while microfinance institutions lack accurate information about them. Thus, financing poor without accurate information about them is considered as a risky decision. In his efforts to overcome this problem, the founder of Grameen Bank in Bangladesh Prof Muhammad Yunus developed the group lending as a main innovation of microfinance services.

The group lending is one of the social services that provided by microfinance institutions which refers to the individuals without collateral who decide to join into solidarity groups to obtain loans from lenders (Armendáriz \& Morduch, 2005). The concept of group lending is usually seen as a main key to solve the problems of imperfect credit market, especially the asymmetric information problems (Ghatak, 2000). The asymmetries information can be the main cause of adverse selection and moral hazard which leads to loan default. The group lending programme in the Grameen Bank is tailored to extend small loans to poor people in rural areas for financing micro and small non-agricultural enterprises without physical collateral. The loans are individually disbursed to the group members while the group is jointly liable for the repayment for each member. The underlying logic of group lending is that the joint liability may leads to mitigate the moral hazard and adverse selection through peer monitoring and screening functions. Paal and Wiseman (2011) demonstrate that offering joint liability loan can bring a high profit to lender compared with the individual liability contracts. The joint liability is also a helpful tool to improve the performance of the group members. Carpena, Cole, Shapiro, and Zia (2012) emphasise that the joint liability has a positive impact on savings discipline and reducing default rates among the borrowers in the Indian microfinance institutions. In addition, group loans has a positive impact on the group members' household expenditure food expenditure as well as the activities of entrepreneurship in Mongolia (Attanasio, Augsburg, Haas, Fitzsimons, \& Harmgart, 2011). However, a few studies give little weight to the group lending and joint liability for example Kenyan microfinance institutions prefer individual lending (Kodongo \& Kendi, 2013). The importance of group liability to repayment rates and improve the performance of the group members has motivated the policymakers, microfinance institutions and researchers to identify and 
simulate the criteria of a successful group formation. For instance, encouraging repeated interaction between group members can increase long-run social ties and enhance social capital among the group members of Village Welfare Services in India which leads to achieve a higher loan repayment rates (Feigenberg, Field, \& Pande, 2011). The self-selection of the group members and its leader is important factor for long term success because it enhances the members' relationship, cooperation and trust. Furthermore, the self-selected groups with pre-existing tied should do better than the groups that formed by researchers (Armendáriz \& Morduch, 2005).

\subsection{Socioeconomic and Characteristics of the Clients and Their Business}

The demographic characteristics such as gender, age, level of education, income, marital status and others have the possibility to affect the clients' performance and their micro and small businesses. The level of clients' education and income are important determinants in the Myanmar microfinance (Lhing, Nanseki, \& Takeuchi, 2013). In addition, level of clients' education, income, gender of the head of household, land holding size, number of crops, and established new enterprise have positive impact on the clients income, while the age of the head of household have negative impact on the clients income

The characteristics of the clients of MFIs such as gender, age, business experience, education, religious, total sales, total household income, distance to the lender office, period of loan approval, the formality of business, and loan monitoring influence the rates of loan repayment in the TEKUN National clients in Peninsular Malaysia (Nawai, Noor, \& Shariff, 2012).

\subsection{A Conceptual Framework}

In order to understand the role of Yemeni and Malaysian microfinance institutions on their clients' wellbeing a conceptual framework has been developed, which is shown below (Figure 2). This has been developed based on an initial literature review undertaken on the impact of microfinance. The conceptual framework consists of six major components; the microcredit services, saving services, nonfinancial services, social services, clients' and small businesses characteristics and the clients' wellbeing.

First, the financial services are the driving force of the socioeconomic development of poor people and poverty reduction. The financial services of microfinance are generally known as the credit and saving, insurance, payment and repayment services (Ledgerwood, 1999). Loan is a main product of microfinance institutions which refers to the small amount of credit given to poor people at reasonable interest for generating income through self-employment. The terms of the given loan are important determinants to the clients' wellbeing and household improvement and their businesses' performance. For example, increasing the size of the given loan is important for extend the market and the size of micro and small enterprises. The flexibility of loan disbursement which includes the facilities of easy access to services, time responsiveness and providing adequate information about the terms of service is important determinants for improving the clients' wellbeing. Moreover, the flexibility of loan repayment policy which includes loan grace period, repayment period, and interest rate all are critical factors for determining the role of microfinance services on clients' wellbeing (Hulme, 1996; Ledgerwood, 1999; Robinson, 2001).

Saving service is another product of microfinance which takes two forms of mandatory and voluntary savings. The mandatory saving is referred to the value of savings that the clients of microfinance are required to save as a condition of obtaining future loan; while the voluntary savings is referred to the amount of savings kept by MFI clients which is not required as a condition of an existing to loan. Both of mandatory and voluntary savings are important for enhancing the capability of poor to cope with the uncertainty shocks and reduce the financial cost of lending and secure a sustainable fund sources (Ledgerwood, 1999; Robinson, 2001). The interest rate on the deposited savings of the clients has the power to help poor in accessing to large size of loans and consolidate their financial position. In addition, the availability of accessing saving accounts helps poor clients to cope with uncertain shocks.

Second, the nonfinancial services such as enterprises development trainings are important factors to effectively use the financial services and advance the clients' wellbeing and their businesses' performance. The commercialization of microfinance institutions led to a massive competition in the arena of microfinance market. This competition forced microfinance institutions to develop and improve their products and services which lead to enhance the sustainability of those institutions through reaching a large size of clients. However, in order to achieve deep outreach, improving the quality of microfinance services and reducing the cost are required. The entrepreneurial and business developments trainings have been recognized as the engine of effectively use the financial services which lead to enhance the performance of the clients. Thus, embedded financial services with entrepreneurial and business development training are inevitable for creating successful entrepreneurs. Ledgerwood (1999) argues that microfinance is not a simple lender; it is also a development tool of human skills 
and capabilities. There are different types of business development and entrepreneurial training. However, this research traces the suggested trainings of Wickham (2001) which include a) business strategy training, b) plan training, c) marketing training, d) finance training, e) project management, f) time management, g) leadership, h) motivation, i) delegation, j) communication, $\mathrm{k}$ ) negotiation

Third, social mediation service has been known as an important factor for facilitating the process of accessing to the financial services without collateral through building social capital between the group members. Social intermediation has been defined as a process in which investments are made in the development of both human resources and institutional capital, with the aim of increasing the self-reliance of marginalized groups, preparing them to engage in formal financial intermediation (Hulme, 1996). Group forming is important for both the lenders and the borrowers. The lenders attempt to reduce the cost of microfinance services through achieving a wide and deep outreach which required free physical collateral facilities while they want to mitigate the risk of asymmetry information. The group liability has shown to be a crucial approach to overcome the challenges of asymmetry information and mitigate the risk of adverse selection through peer monitoring and screening functions. In addition, the group members have the opportunities to easily access to loan services and extend the size of the required loan as well as sharing the information and improve the overall performance of the group members.

\section{Conclusion}

The role of microfinance institutions in poverty reduction and wellbeing improvement has attracted the policymakers' attention in the developing countries across the globe. Yet, the clear evidence on the positive impact of microfinance is no exists. What is the role of microfinance on the poor wellbeing? This question is always repeated among the academicians and the policymakers in the government and non government agencies. Therefore, this research attempts to uncover the role of the Malaysian and Yemeni microfinance institutions on the clients' wellbeing. The intervention of microfinance institutions is consists of three major functions of financial, nonfinancial and social intermediation services which have significant impact on the poor wellbeing which manifested in the clients' household, empowerment and their micro and small enterprises' performance. The Malaysian microfinance institutions are Amanah Ikhtir Malaysia, Yayasan Usaha Maju and Economic Fund for National Entrepreneurs, while the Yemeni microfinance is Al-Amel Bank.

The outcomes of the study could provide clear evidence about the impact of microfinance on the poor wellbeing which contributes to the body knowledge of the literature. It also will hopefully provide valuable guidelines, to the policymakers in how to improve the outreach and sustainability of microfinance institutions generally and the Malaysian and Yemeni microfinance institutions particularly. The research presented in this paper is a part of an ongoing PhD research at Faculty of Business Management and Technopreneurship in the Universiti Teknikal Malaysia Melaka UeTM to develop a framework of the role of microfinance intervention services on the clients' wellbeing in the Malaysian and Yemeni microfinance institutions. 


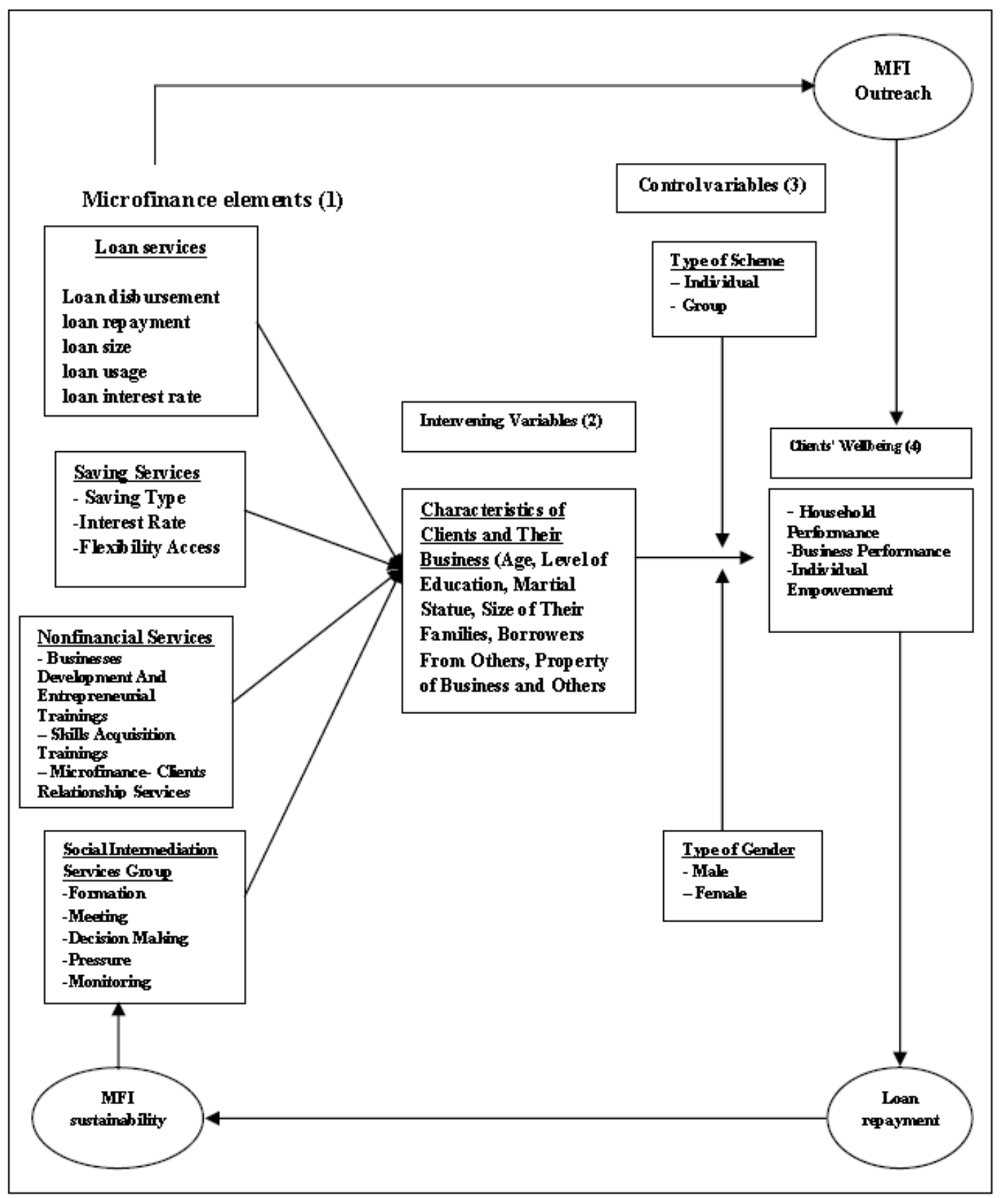

Figure 2. Proposed a conceptual framework for microfinance services in the Malaysian and Yemeni MFIs

\section{References}

Ahmad, S. Z. (2012). Microfinance for women micro and small-scale entrepreneurs in Yemen: Achievements and challenges. International Journal of Entrepreneurship and Small Business, 16(1), 102-120. http://dx.doi.org/10.1504/IJESB.2012.046920

Angioloni, S., Kudabaev, Z., Ames, G., \& Werzstein, M. (2013). Micro-credit impact in Kyrgyzstan: A study case. Southern Agricultural Economics Association, 23.

Armendáriz, D. A., \& Morduch, J. (2005). The Economics Microfinance. UK: Cambridge, MA: The MIT Press.

Attanasio, O., Augsburg, B., Haas, D. R, Fitzsimons, E., \& Harmgart, H. (2011). Group lending or individual lending? Evidence from a randomised field experiment in Mongolia (pp. 48). Working Paper W11/ 20 University College, London and Institute for Fiscal Studies, London. 
Bakhtiari, B. (2006). Microfinance And Poverty Reduction: Some International Evidence. Business \& Economics Research, 5(12), 65-71.

Behr, P., \& Sonnekalb, S. (2012). The effect of information sharing between lenders on access to credit, cost of credit, and loan performance - Evidence from a credit registry introduction. Journal of Banking \& Finance, 35, 3017-3032. http://dx.doi.org/10.1016/j.jbankfin.2012.07.007

Brannen, C. (2010). An Impact Study of the Village Savings and Loan Association (VSLA) Program in Zanzibar, Tanzania. Degree of Bachelor of Arts with Departmental Honors in Economics, Wesleyan University.

Burjorjee, D., \& Jennings, M. (2008). Microfinance Gender Study: A Market Study of Women Entrepreneurs in Yemen. Sana'a: Social Fund for Development.

Campaign, M. S. (2012). State of the Microcredit Summit Campaign Report. Technical Report: A project of Results Educational Fund. USA.

Carpena, F., Cole, S., Shapiro, \& Zia, B. (2012). Liability Structure in Small- Scale Finance: Evidence from a Natural Experiment (pp. 34). World Bank Policy Research Working Paper No. WPS 5427, World Bank, Washington, D.C.

CGAP. (2013). What is microfinance? Retrieved September 14, 2013, from http://www.microfinancegateway.org/p/site/m/template.rc/1.26.12263/\#1

Charitonenko, S., \& Afwan, I. (2003). Commercialization of Microfinance Indonsia. Indonsia: Asian Development Bank.

Christen, R. B., \& Drake, D. (2002). Commercialization: The New Reality of Microfinance. In The Commercialization of Microfinance (Ed.), Deborah Drake and Elisabeth Rhyne (pp. 1-20). Bloomfield, CT: Kumarian Press.

Dunford, C. (2001). Building Better Lives Sustainable Integration of Microfinance and Education in Child Survival, Reproductive Health, and HIV/AIDS Prevention for the Poorest Entrepreneurs. Freedom from Hunger. Journal of Microfinance, 3(2), 25.

Ebimobowei, A., Sophia, J. M., \& Wisdom, S. (2012). An Analaysis of Microfinance and poverty Reduction in Bayelsa State of Nigeria. Arabian Journal of Business and Management Review, 1(7), 38-57.

Feigenberg, B., Field, E., \& Pande, R. (2011). The Economic Returns to Social Interaction: Experimental Evidence from Microfinance. Oxford University Press.

Field, E., Pande, R., \& Park, J. (2012). Repayment Flexibility Can Reduce Financial Stress: A Randomized Control Trial with Microfinance Clients in India. Plos One, 7, e45679. http://dx.doi.org/10.1371/journal.pone.0045679

Garikipati, S. (2008). The Impact of Lending to Women on Household Vulnerability and Women's Empowerment: Evidence from India. World Development, 36(12), 2620-2642. http://dx.doi.org/10.1016/j.worlddev.2007.11.008

Ghatak, M. (2000). Screening by the Company Tou Keep: Liability Lending and the Peer selection Effect. The Economic Journal, 110(465), 601-631. http://dx.doi.org/10.1111/1468-0297.00556

Godquin, M. (2004). Microfinance Repayment Performance in Bangladesh: How to Improve the Allocation of Loans by MFIs. World Development, 32(11), 1909-1926. http://dx.doi.org/10.1016/j.worlddev.2004.05.011

Haile, H. B., Bock, B., \& Folmer, H. (2012). Microfinance and female empowerment: Do institutions matter? Women's Studies International Forum, 35, 256-265. http://dx.doi.org/10.1016/j.wsif.2012.04.001

Hamdan, H., Othman, P. F., \& Hussin, W. S. W. (2012). The importance of monitoring and Entrepreneurship Concept as Future Direction of Microfinance in Malaysia: Case Study in State of Selangor. Journal of Global Entrepreneurship, 3(1), 25.

Holvoet, N. (2004). Impact of Microfinance Programs on Children's Education" Do the Gender of the Borrower and the Delivery Model Matter? Journal of Microfinance, 6(2), 1-23.

Hulme. (1996). Finance Against Poverty (Vol. 1). London: Routledge.

Hulme. (2000). Impact Assessment Methodologies for Microfinance: Theory, Experience and Better Practice. World Development, 28(1), 79-98. http://dx.doi.org/10.1016/S0305-750X(99)00119-9

Imai, S. K., \& Azam, M. H. (2010). Does Microfinance Reduce Poverty in Bangladesh? New Evidence from 
Household Panel Data, Discussion Paper, DP2010-24, Kobe University, September., pp. 39.

Johnson, S., \& Rogaly, B. (1997). Microfinance and Poverty Reduction. UK: Oxfam.

Karlan, D. S., \& Valdivia., M. (2006). Teaching entrepreneurship: Impact of business training on microfinance clients and institutions. United States of America: Economic Growth Center (EGC), Yale University.

Khandker, S. R. (2005). Microfinance and Poverty: Evidence Using Panel Data from Bangladesh. The World Bank Economic Review, 19, 263-286. http://dx.doi.org/10.1093/wber/lhi008

Kodongo, O., \& Kendi, L. (2013). Individual lending versus group lending: An evaluation with Kenya's microfinance data. Development Finance, 3, 99-108.

Ledgerwood. (1999). Microfinance Handbook: An Institutional and Financial Perspective. Washington: D.C: World Bank. http://dx.doi.org/10.1596/978-0-8213-6615-8

Ledgerwood, J., \& White, V. (2006). Transforming Microfinance Institutions Providing Full Financial Services to the Poor. World Bank.

Lhing, N. N., Nanseki, T., \& Takeuchi, S. (2013). An Analysis of Factors Influencing Household Income: A Case Study of PACT Microfinance in Kyaukpadaung Township of Myanmar. American Journal of Human Ecology, 2(2), 94-102. http://dx.doi.org/10.11634/216796221302320

Littlefield, E., Murduch, J., \& Hashemi, S. (2003). Is Microfinance an Effective Strategy to Reach the Millennium Development Goals? CGAP Focus Note 24 (pp. 11). Washington, D.C: Consultative Group to Assist the Poor.

Mamun, A. A., Adaikalam, J., \& Wahab, S. A. (2012). Investigating the Effect of Amanah Ikhtiar Malaysia's Microcredit Program on Their Clients Quality of Life in Rural Malaysia. International Journal of Economics and Finance, 4(1), 192-203.

Mansour, A. (2011). Small and Micro Enterprises Development in Yemen and Future Prospects. Yemen: Ministry of planning and international cooperation Social Fund for Development Yemen.

Mensah, S. N., \& Benedict, E. (2010). Entrepreneurship training and poverty alleviation Empowering the poor in the Eastern Free State of South Africa. African Journal of Economic and Management Studies, 1(2), 138-163. http://dx.doi.org/10.1108/20400701011073464

Mokhtar, S. H. (2011). Microfinance Performance in Malaysia. Doctor of Philosophy, Lincoln University, New Zealand. Retrieved from http://hdl.handle.net/10182/4186

Monitor, M. (2010). Microcapital Breif: Malaysian Microfinance Institution (MFI), Amanah Ikhtiar Malaysia (AIM), Claims "World's Highest" Microcredit Repayment Rate of 99.2 Percent. Retrieved July 23, 2010, from http://www.microcapital.org/microcapital-brief-malaysian-microfinance-institution-mfi-amanah-ikhtiar-m

Morduch, J., \& Hayley, B. (2002). Analysis of the Effects of Microfinance on Poverty Reduction. New York University, New York: NYU Wagner Working Paper 1014.

Morduch., M. (1999). The Microfinance Promise. Economic Literature, 37(4), 1569-1614. http://dx.doi.org/10.1257/jel.37.4.1569

Mutua, A. K. (1994). "The Juhudi Credit Scheme. From a Traditional Integrated Method to a Financial Systems Approach" The New World of Microenterprise Finance. Building Healthy Financial Institutions for the Poor, Kumarian Press, Connecticut. pp. 268-276.

Nader, Y. F. (2008). Microcredit and the socio-economic wellbeing of women and their families in Cairo. The Journal of Socio-Economics, 37, 644-656. http://dx.doi.org/10.1016/j.socec.2007.10.008

Narayan, D. (2002). Empowerment and Poverty Reduction: A Sourcebook. The World Bank.

Nawai, N., \& Shariff, M. N. M. (2012). Factors affecting repayment performance in microfinance programs in $\begin{array}{lllll}\text { Malaysia. Procedia - Social and Behavioral Sciences, } & 62(24), & \end{array}$ http://dx.doi.org/10.1016/j.sbspro.2012.09.136

Nawai, N., \& Shariff, M. N. M. (2011). The Importance of Micro Financing to the Microenterprises Development in Malaysia's Experience. Asian Social Science, $7(12), 13$. http://dx.doi.org/10.5539/ass.v7n12p226

Omar, M. Z., Noor, S. C. M., \& Dahalan, N. (2012). The Economic Performance of the Amanah Ikhtiar Malaysia 
Rural Microcredit Programme: A Case Study in Kedah. World Journal of Social Sciences, 2(5), 286-302.

Paal, B., \& Wiseman, T. (2011). Group insurance and lending with endogenous social collateral. Journal of Development Economics, 94, 30-40. http://dx.doi.org/10.1016/j.jdeveco.2009.11.009

Parvin, L., Rahman, W. M., \& Jia, J. (2012). Determinates of Women Micro-entrepreneurship Development: An Empirical Investigation in Rural Bangladesh. International Journal of Economics and Finance, 4(5), 254-260. http://dx.doi.org/10.5539/ijef.v4n5p254

Robinson, M. S. (2001). The Microfinance Revolution, Sustainable Finance for the Poor. Washington, D.C.: World Bank. http://dx.doi.org/10.1596/0-8213-4524-9

Rutherford, S., Maniruzzaman, M., Sinha, S., \& Acnabin, C. (2003). Grameen II At the end of 2003 A 'grounded view' of how Grameen's new initiative is progressing in the villages: Paper written for MicroSave. Kampala: MicroSave-Africa.

Schreiner, M. (2000). Informal Finance and the Design of Microfinance (Vol. 11, pp. 637-640). United States: George Warren Brown School of Social Work, Washington University.

Simeyo, O., Lumumba, M., Nyabwanga, R. N., Ojera, P., \& Odondo, A. J. (2011). Effect of provision of micro finance on the performance of micro enterprises: A study of youth micro enterprises under Kenya Rural Enterprise Program (K-REP), Kisii County, Kenya. African Journal of Business Management, 5(20).

Statistics, D. O. (2005). Census of Establishments and Enterprises. Kuala Lumpur, Malaysia.

Swaina, R. B., \& Wallentin, F. Y. (2009). Does microfinance empower women? Evidence from self-help groups in India. Taylor \& Francis Group, 23(5), 541-556.

Wisniwski, S. (1998). Savings in the Context of Microfinance Lessons Learned from Six Deposit-Taking Institutions. Paper presented at the paper presented at Interamerican Forum on Microenterprise, Mexico City, 26-28 March 1998.

Yeboah, E. H. (2010). Microfinance in Rural Ghana: A view from Below. Degree of Doctor Philosophy, Birmingham, United Kingdom.

\section{Copyrights}

Copyright for this article is retained by the author(s), with first publication rights granted to the journal.

This is an open-access article distributed under the terms and conditions of the Creative Commons Attribution license (http://creativecommons.org/licenses/by/3.0/). 